\title{
疎水性リン脂質ポリマーの吸着性制御と刺激低減機能の評価
}

\author{
日本油脂株式会社, 金沢大学大学院自然科学研究科 山本宣之 \\ 金沢大学大学院自然科学研究科 山岸忠明 $\cdot$ 中本義章
}

\section{Adsorption Control and Estimation of Stimuli-reducing Function of Hydrophobic Phospholipid Polymer}

\author{
Nobuyuki Yamamoto $^{* 1, * 2}$, Tada-Aki Yamagishi ${ }^{* 2}$, and Yoshiaki Nakamoto ${ }^{* 2}$ \\ ${ }^{* 1}$ Section II, Tsukuba Corporate Research Laboratory, Life Science Products Division, \\ NOF Corporation, 5-10 Tokodai, Tsukuba, Ibaraki 300-2635, Japan \\ *2 Graduate School of Natural Science \& Technology, Kanazawa University, \\ Kakuma-machi, Kanazawa, Ishikawa 920-1192, Japan
}

\begin{abstract}
In this study, adsorption control and estimation of stimuli-reducing function of hydrophobic phospholipid polymer were carried out. The hydrophobic phospholipid polymer consisting of 2-methacryloyloxyethyl phosphorylcholine and stearyl methacrylate (PMS) was synthesized by ordinary radical polymerization. PMS nanodispersion was prepared by the self-aggregation technique. Surface potential changes of PMS nano-dispersion were studied by laser-Doppler electrophoresis at $\mathrm{pH}$ conditions of 2 to 8. PMS nano-dispersion was positively charged under acidic conditions, and electrostatic adsorption to cotton fiber was observed by X-ray photoelectron spectroscopy (XPS) analysis. On the other hand, under neutral and basic conditions, non-charged and negatively charged nano-dispersions were not adsorbed. A fluorescence microscope observation of cotton fibers treated with PMS nano-dispersion that contained Nile Red suggested that a lamellar structure was formed in the PMS coat layer. The sulfur/carbon ratio (S/C) evaluated by XPS analysis showed that the amount of alkyl sulfate, which is a main component of laundry detergent, on the PMS treated cotton fibers was smaller than that on non-treated fibers after a laundry/rinse process. Cytotoxicity studies using three-dimensional skin models showed that the toxicity of surfactant was reduced by the PMS treatment.
\end{abstract}

(Received 12 September, 2006 ; Accepted 10 November, 2006)

\section{1. 緒 言}

アトピー性皮膚炎は増悪・寛解を繰り返す，掻痒のあ る湿疹を主病変とする疾患であり, 国内の若年層におけ る有症率は約 $10 \%$ にのぼることが明らかとなっている [1]. 日本皮膚科学会が提唱する「アトピー性皮膚炎治療ガイ ドライン」によれば, 症状緩和のための一項目として「刺 激が少ない衣服の着用」が掲げられており [2], 低刺激な 衣類の実現を目指して様々な研究が行われている. 例え ば，アレルゲンの吸着・除去および皮膚上における黄色 ブドウ球菌の異常繁殖の抑制を目的とした金属フタロシ アニン加工や $[3]$, 繊維と皮膚との摩擦により発生する痒 み・かさつきの緩和を目的とした滑り性の高い柔軟剤の 開発などについての報告がある $[4]$.

一方, 我々はこれまでに, 分子内に生体膜リン脂質と 同じホスホリルコリン基を有する 2-メタクリロイルオキ シエチルホスホリルコリン (MPC) を主成分とする様々な ポリマーを開発し, 医療用具, 生化学用機器, コンタク
トレンズケア用品, 化粧品などの用途に展開してきた $[5]$. MPC ポリマーは, 高い保湿性や抗蛋白吸着能を示寸こと が知られているが, 近年, 界面活性剤の毒性低減効果が 実証されるなど，新しい知見も得られている $[6]$.

最近では, MPC ポリマーの中でも特に, 生体膜リン脂 質と極めて近い構造を目指して設計されたステアリルメ タクリレート (SMA) との共重合体 (PMS,Fig.1)について検 討が進められており，これまでに，自己組織化現象を利 用した分散法により $50 \mathrm{~nm}$ 以下の平均粒径を有する微粒 子を形成すること [7]，また，このナノ粒子を乾燥させる と $6 \mathrm{~nm}$ 程度の長周期を持つ微細なラメラ構造を形成する ことが明らかとなっている [8] (Fig.2)。このラメラ構造は, 表皮においてバリア機能を司る角層細胞間脂質と類似性 が高く, また, 表面摩擦を低減させる機能もあることか ら, 皮膚および毛髪の修復用素材として開発が進められ ている[9-11].

これらの知見から, PMS を用いて繊維上に角層細胞間 脂質類似のラメラ層を形成させることができれば，肌に 
対する負担が極めて少ない肌着を実現することができる と考えられるが，そのためには，簡便かつ高効率な加工 法の確立が必要である，そこで本研究では，PMSナノ粒 子の表面電位を制御することにより, 繊維に対して効率 良く吸着させる方法について検討した。 また, 得られた 加工生地について, 表面分析による PMS の吸着性評価と, 蛍光顕微鏡による PMS 皮膜層の観察を行った.また, PMS 加工による洗濯洗剤の付着防止効果, および, 界面活性 剂の毒性低減効果について評価した.

\section{2. 実 験}

\section{1 試薬}

2-メタクリロイルオキシエチルホスホリルコリン (MPC), ステアリルメタクリレート (SMA), 重合開始剤 t-ブチル パーオキシネオデカノエート(商品名「パーブチル ND」) (い ずれも日本油脂株式会社製) は, 精製せずに用いた。蛍光 物質の Nile Red(ICN Biomedicals 製), および, その他の 試薬については，市販の試薬特級品を用いた。

\section{2 ナノ粒子の調製}

既報 $[1]$ に従い, MPC と SMA のランダム共重合体(PMS ; $\mathrm{MPC} / \mathrm{SMA}=30 / 70 \mathrm{~mol} / \mathrm{mol}$ ) のナノ粒子を含む水分散液(以 下，NS），および，ポリマーに対してNile Red を $0.1 \%$ 内 包化したナノ粒子分散液 (以下, F-NS) を調製した。

\section{3 ナノ粒子の表面電位測定}

NS をイオン交換水で希釈してポリマー濃度を $1 \mathrm{~g} / \mathrm{L}$ と した後, 塩酸および水酸化ナトリウム水溶液を適量添加 して pH 調整を行い, 電気泳動光散乱法(レーザードップ ラー法)により, PMS ナノ粒子表面の表面電位を測定した。

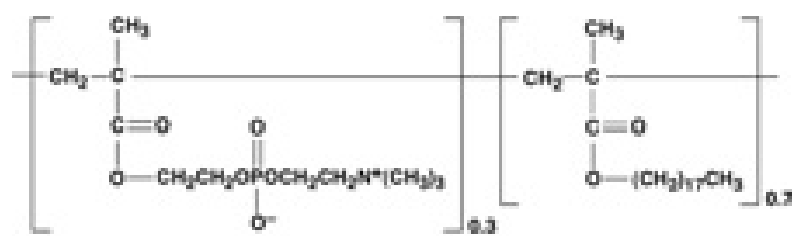

Fig. 1 Chemical structure of poly (2-methacryloyloxy ethyl phosphorylcholine / stearyl methacrylate) (PMS).

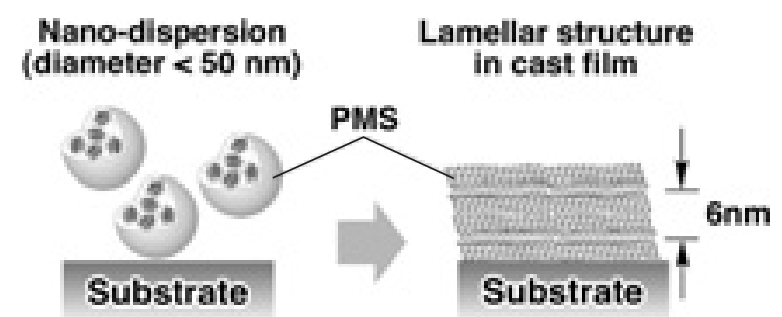

Fig. 2 Schematic illustration of lamellar structure formed by drying of PMS nano-dispersion.

\section{4 綿生地の加工}

NS またはF-NS をイオン交換水で希釈してポリマー濃 度を調整し, 塩酸および水酸化ナトリウム水溶液を適量 添加して $\mathrm{pH}$ 調整を行った。この溶液にJIS 標準白布綿(以 下, JIS 綿) を投入し, 室温にて 30 分間撹拌した後, 取り 出して脱水, 乾燥させた.

\section{$2.5 X$ 線光電子分析および蛍光顕微鏡観察}

$\mathrm{NS}$ 加工 (ポリマー濃度 $0.1 \mathrm{~g} / \mathrm{L}, \mathrm{pH} 3.3,3.8,7.4$ ) した JIS 綿についてX線光電子分析 (X-ray Photoelectron Spectroscopy, XPS)を行ない, リン原子のピーク強度から, 䋊維 表面に対するPMS の吸着性を評価した。

また, F-NS 加工 (ポリマー濃度 $0.1 \mathrm{~g} / \mathrm{L}, \mathrm{pH} 3.3$ ) した JIS 綿をほぐして単繊維とし, 蛍光観察用スライドガラスに 貼り付けて蛍光顕微鏡観察を行なった. 単繊維の断面に ついては, OCT コンパウンド(Tissue-Tek 製)を満たした クリオモルド(Tissue-Tek 製) 中に複数の単繊維を包埋後, $-20^{\circ} \mathrm{C}$ にて凍結し, クリオスタット(HM500OM, Microm 製)を用いて作製した厚さ約 $5 \mu \mathrm{m}$ の凍結切片を蛍光観察用 スライドガラスに貼り付けて蛍光顕微鏡観察を行なった.

\section{6 洗剂残存性の評価}

$\mathrm{NS}$ 加工 (ポリマー濃度 0.2 または $0.4 \mathrm{~g} / \mathrm{L}, \mathrm{pH} 3.3$ )した JIS 綿を $5 \times 5 \mathrm{~cm}$ に切断して試験布とした.アルキル硫酸 塩を主成分とする家庭用洗剂をイオン交換水で希釈し, 濃度 $5 \mathrm{~g} / \mathrm{L}$ の洗剂溶液を調製した後, この洗剂溶液 $50 \mathrm{~mL}$ 中に試験布を投入して，5分間擋找した。 その後， $50 \mathrm{~mL}$ のイオン交換水中で 5 分間撹挥してすすぎ操作を行った. す寸ぎ操作 $0,1,2$ 回の試験布について乾燥後に XPS 測定 を行い, 表面に存在する硫黄原子と炭素原子の存在数比 (S/C) を算出した。得られた $\mathrm{S} / \mathrm{C}$ 值から, 試験布表面にお ける洗剤残存性を評価した。

\section{7 三次元培養皮膚を用いた毒性低減効果の評価}

$\mathrm{NS}$ 加工 (ポリマー濃度 0.1 または $0.4 \mathrm{~g} / \mathrm{L}, \mathrm{pH} 3.3$ )した JIS 綿をパンチャーで直径 $6.5 \mathrm{~mm}$ の円形に打ち抜いて試 験布とした。また，JIS L-0848 に従って調製された酸性人 工汗液中に, 細胞毒性物質としてドデシル硫酸ナトリウ ム $(\mathrm{SDS}) 7 \mathrm{~g} / \mathrm{L}$ を溶解させて, 試験液とした.

三次元培養皮膚モデルについては，「Vitrolife Skin」(24 ウェルタイプ, グンゼ株式会社製)および「LabCyte EPIMODEL」(24 ウェルタイプ, ジャパン・ティシュ・エンジ ニアリング製)を使用し，1検体あたり 3 個の皮膚モデル を用いて評価した。

毒性低減効果の評価については, JIS L-1918 を参考にし て, 以下の手順にて行った。まず，培養皮膚表面に試験 布を貼付し，この試験布に対して 2 倍重量の試験液を含 浸させて, $\mathrm{CO}_{2}$ インキュベータ内に 24 時間, 静置した. MTT 法により生細胞を染色した後, 皮膚モデルをポンチ でくり抜き, 所定の抽出溶媒にて色素を抽出して, 抽出 
液の吸光度を測定した. SDS を含まない酸性人工汗液を 含浸させた未加工 JIS 綿を陰性対照(細胞生存率 $100 \%$ ) と し, 得られた吸光度から, 3 個の皮膚モデルにおける細胞 生存率の平均值を算出した。

\section{8 測定装置および測定条件}

PMS ナノ粒子の表面電位測定については，アルゴンイ オンレーザーを光源に持つ Nicomp 380ZLS (Particle Sizing Systems 製)を用いて, $25^{\circ} \mathrm{C} に て$ 行った。蛍光顕微鏡観察 については，蛍光モジュール BH2-DMG(励起主波長 546 $\mathrm{nm}$ )を備えた落射蛍光顕微鏡 BHS-RFC (Olympus 製)を用 いた. X 線光電子分析 $(X P S)$ にる表面元素分析について は, JPS-9200 (日本電子製)を用いて $\mathrm{X}$ 線 $(\mathrm{MgK} \alpha)$ を出力 10 $\mathrm{kV}, 10 \mathrm{~mA}$ にて照射し, 測定を行った. 三次元培養皮膚試 験における MTT 染色後の色素定量については, 96 ウェ ルプレートリーダ SPECTRA MAX 250(Molecular Devices 製)を用いて波長 $570 \mathrm{~nm}$ での吸光度を測定した。

\section{3. 結果と考察}

\section{1 ナノ 粒子の表面電位}

生体膜リン脂質に含まれる極性基であるホスホリルコ リン基 (PC 基)には, リン酸残基とコリン残基が同数存在 するために，理論上は電気的に中性であると考えられて いる. また, ジパルミトイルホスホリルコリンを主成分 とする PC リポソームの測定例においても, 緩衝液中では 表面電位が $0 \mathrm{mV}$ である事が報告されている[12]. しかし ながら, 液中の塩濃度が極めて低い場合には表面電位は $\mathrm{pH}$ に応じて変化し, $\mathrm{pH} 4$ 付近を等電点として酸性側では 正電荷, 中性から塩基性側では負電荷を帯びることが明 らかにされている $[13,14]$. PC リポソームが中性から塩 基性条件下で負に帯電する理由については, PC 基の部分 的な加水分解や, 溶液中に存在する負電荷成分のリポソー ム表面への吸着などが考えられる.また, $\mathrm{pH}$ の低下に伴っ て表面電位が上昇する理由については，PC 基中のリン酸 残基に対して水素イオンが付加することにより，コリン 残基の正電荷が表面電位に影響を及ぼすためと考えられ る.これらの知見から, PMS ナノ粒子中の PC 基につい て, 溶液の $\mathrm{pH}$ 調整により荷電状態を制御できる可能性が 示唆された.

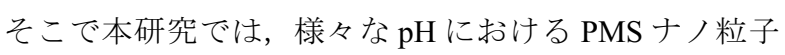
の表面電位について電気泳動光散乱法により測定を行っ た. その結果, PMS ナノ粒子は $\mathrm{pH} 3.8$ 付近を等電点とし て, 酸性側では正電荷, 中性から塩基性側では負電荷を 帯びることが明らかとなった (Fig. 3).

\section{2 綿に対する吸着性}

セルロースは分子鎖の末端が酸化されやすく, 酸化に よりカルボキシル基を生じる. 綿はセルロースの集合組 織であるため, 綿を水中に置くと表面が負電荷を帯びる
ことが知られている. 杉原らによれば, 水中における木 綿の表面電位は-2 から-10 mV 程度であることが報告さ れている[15]。この性質を利用して, 例えば繊維に柔軟 性を付与するために, 長鎖アルキル基を有するカチオン 性界面活性剂やアミノ変性シリコーンを静電吸着させる 方法が広く用いられている。

本研究では, pH 調整により表面の荷電状態を変化させ たPMSナノ粒子を用いて, 綿に対する吸着性を評価した. XPS を用いた表面リン原子の分析から，溶液の $\mathrm{pH}$ を 3.3 に制御した系ではポリマーの吸着が見られたのに対して, pH 3.8 以上ではほとんど吸着が見られなかった (Fig. 4). これらの結果から, pH 調整により正に帯電した PMS ナ ノ粒子が, 水中で表面が負に帯電した綿に対して静電吸 着したと考えられる.

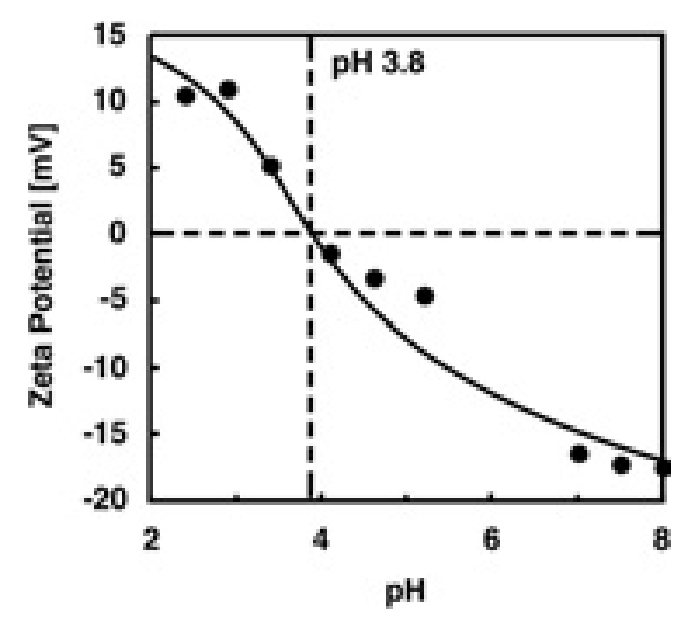

Fig. 3 Zeta potential profile of PMS nano-dispersion as a function of $\mathrm{pH}$.

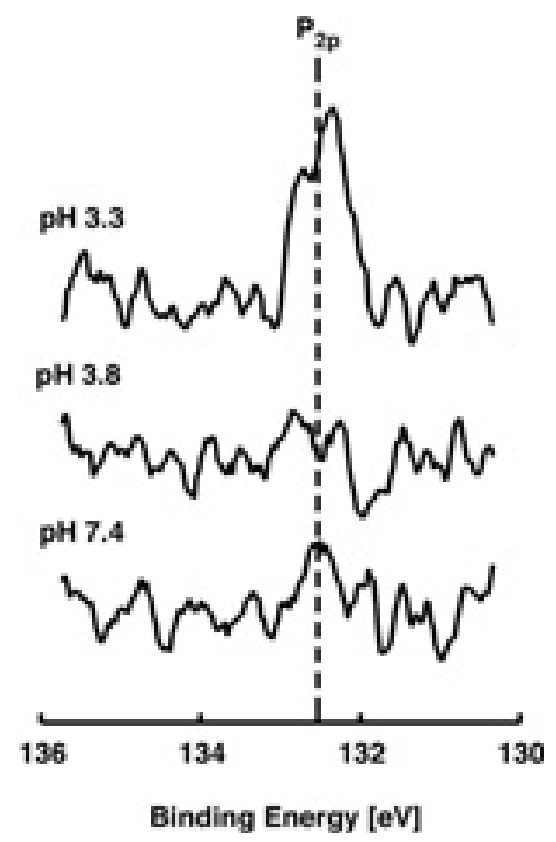

Fig. 4 XPS spectra of $\mathrm{P}_{2 \mathrm{p}}$ on cotton fabric surface treated with PMS nano-dispersion at various $\mathrm{pH}$. 

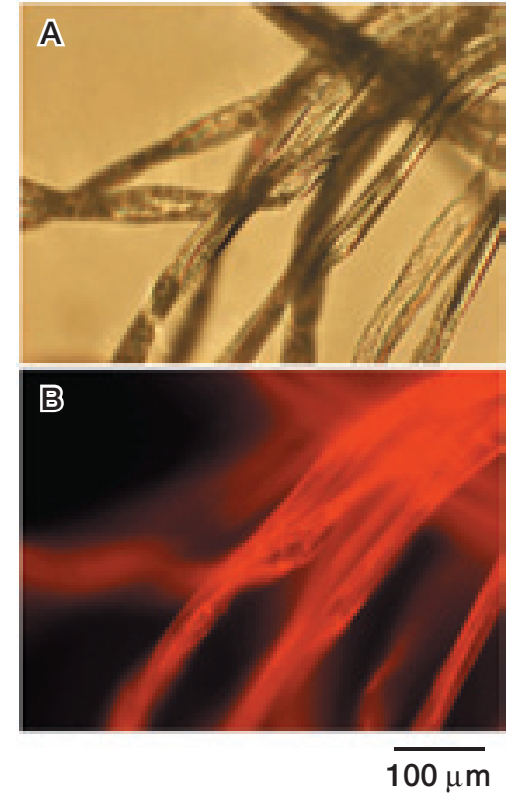

Fig. 5 Optical micrographs of the surface of JIS cotton fibers treated with PMS nano-dispersion containing Nile Red: (A) Brightfield image, (B) Fluorescence image.
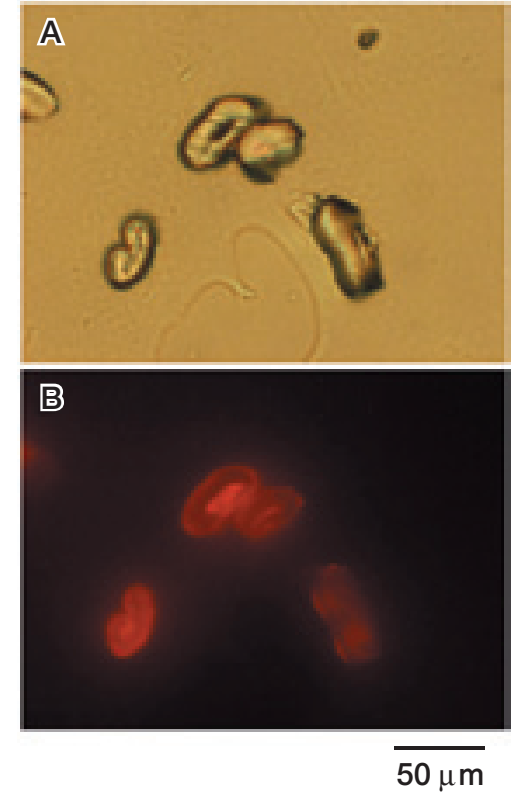

Fig. 6 Optical micrographs of cross-section of JIS cotton fibers treated with PMS nano-dispersion containing Nile Red: (A) Brightfield image, (B) Fluorescence image.

\section{3 蛍光顕微鏡観察}

Nile Red を内包化したPMS ナノ粒子を用いて，酸性条 件下にて綿への吸着加工を行なった. 得られた試料を単 繊維にほぐして蛍光顕微鏡観察を行なったところ, 繊維 表面における蛍光が確認された (Fig. 5). Nile Red は疎水 性の蛍光プローブであり, 極性環境下ではほとんど蛍光 を発しないが，非極性環境下では強い蛍光を示すことが
知られている $[16]$. 本試験において明瞭な蛍光が確認さ れたことから, PMS 中のステアリル基が凝集した疎水場 を形成しており， Nile Red はその中に存在すると考えられ る.これらの結果から, 綿繊維表面における PMS のラメ ラ層形成が示唆された。また, 単繊維の断面観察におい て繊維の周囲に蛍光が強く見られたことから, PMS が繊 維表面を被覆していることが明らかとなった(Fig. 6).PMS 被覆層の正確な厚さを断面像から判断することは困難で あるが，少なくともサブミクロン程度の厚さをもつこと が推察される.

\section{4 洗剂残存性}

アルキル硫酸塩 (AS) は優れた洗浄効果を有する界面活 性剂であり, 洗濯洗剤の主成分として多く用いられてい る.しかしながら, 洗濯後の寸寸ぎが不十分な場合には 生地に残留し, 皮膚炎症状を増悪させることが指摘され ている.「厚生労働科学研究・アトピー性皮膚炎治療ガイ ドライン 2005」においても「洗剤はできれば界面活性剂 の含有量の少ないものを使用する」事が推奨されており [1], また, 洗剤を使わずに洗濯が可能な洗濯機が市販さ れるなど，アトピー性皮膚炎患者のみならず，一般消費 者における関心も高い.

本研究では, PMS 加工した JIS 綿を洗濯した際に, 繊 維表面に残存する AS 量についてXPSにより評価した. その結果, 加工濃度の増加に従って, 繊維表面における AS 残存量が減少した (Fig. 7). また 2 回のすすぎを行っ た試料について, 未加工布では AS が検出されたのに対し て, PMS 加工布では検出限界以下まで減少した。これら の結果から, PMS 加工した綿纎維は AS の付着を妨げる こと, また，付着した ASについても，す寸ぎによって容 易に除去されることが明らかとなった。

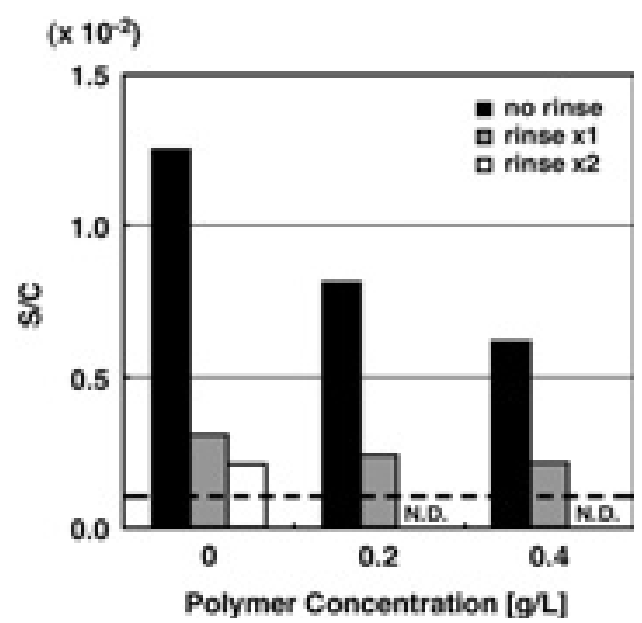

Fig. 7 S/C obtained from XPS quantitative analysis of PMS treated cotton fabric after washing with laundry detergent. Break line denotes the minimum detectable quantity of $\mathrm{S} / \mathrm{C}$ (approx. $\left.0.1 \times 10^{-2}\right)$. 


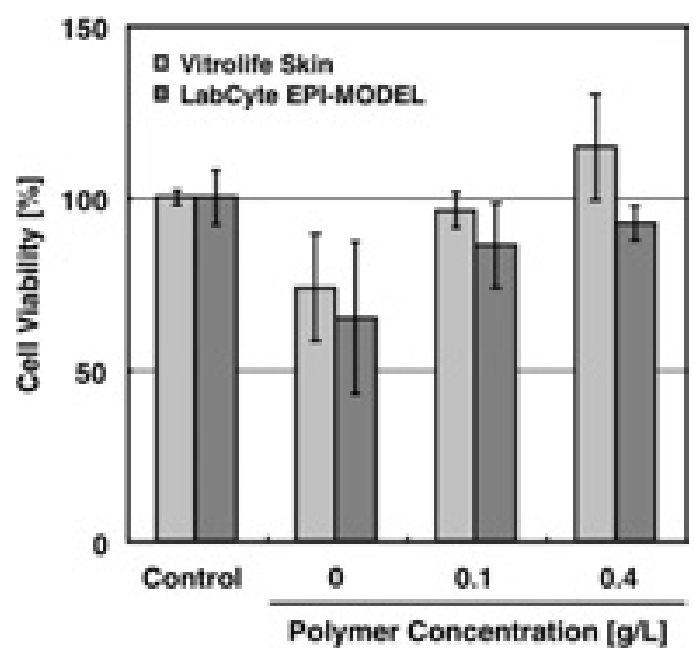

Fig. 8 Cell viability in three-dimensional skin model attached to PMS treated cotton fabric for 24 hours. The specimen was instilled with artificial sweat containing $7 \mathrm{~g} / \mathrm{L}$ of sodium dodecyl sulfate as a cytotoxic reagent.

\section{5 毒性低減効果}

三次元培養皮膚はヒ卜由来の皮膚細胞を三次元的に再 構築した細胞モデルであり, 近年, 化粧品や繊維製品の 皮膚一次刺激を予測するための有力な in vitro 評価系とし て多く用いられるようになってきた，皮膚モデルを検体 に一定時間接触させた後の細胞生存率と, 動物試験にお ける皮膚一次性刺激の評価点数 (Draze 法) は高い相関性を 示寸事が報告されており [17]，ヒトが䋐維製品を着用し た際の化学的刺激の有無を予測することが可能な評価法 として, JIS L-1918「繊維製品の皮膚一次刺激性試験方法 一培養ヒト皮膚 モデル法」として標準化されている. 本 研究ではこれを一部改変し, 細胞毒性を示寸界面活性剂 であるSDS を試験布に含浸させて試験を行うことにより， PMS 加工によって SDS の毒性が低減されるか， 2 種類の 培養皮膚モデルを用いて検討した。

試験の結果, PMS 加工濃度の増加に従って細胞生存率 が向上したことから, PMS 加工は SDS の毒性を低減させ ることが明らかとなった (Fig. 8).Vitrolife Skin は真皮と 表皮からなるモデル，LabCyte EPI-MODEL は表皮のみか らなるモデルであるが，いずれの培養皮膚モデルにおい ても同様な傾向であった.

SDS の毒性を低減させる機構として，(a) ポリマー皮膜 中に SDS が吸着されることにより皮膚への移行が妨げら れた，(b)生地から溶出した PMS が SDS と相互作用する ことにより毒性を低減させた，(c)生地から溶出した PMS が細胞と相互作用することにより SDS に対する耐性が付 与された，などが考えられる。洗剤の残留性試験から， ポリマー皮膜上には活性剤が残留しにくいことが明らか となっているため, (a)の可能性は低い. 従って, PMS ナ ノ粒子加工による毒性低減機能は, (b)または (c) の機構 に基づき, 繊維表面に付着したポリマーが少量溶出する
ことにより，発現されると考えられる．

\section{4. 結 論}

本研究では, 疎水性リン脂質ポリマー(PMS)のナノ粒 子について, 表面電位による繊維への吸着性制御, およ び, 吸着加工によりもたらされる洗剂付着防止効果と毒 性低減効果について評価した。

まず, 電気泳動光散乱法による表面電位測定から, PMS ナノ粒子は $\mathrm{pH}$ に依存して表面電位を変化させ, 中性から 塩基性条件下ではゼロまたは負に帯電するのに対して, 酸性条件下では正に帯電することが明らかとなった，表 面が正に帯電する条件で綿繊維を加工寸ることにより， 低濃度でも効率よく吸着することが XPS 測定から明らか となった. また, 蛍光顕微鏡観察から, PMS が綿繊維の 表面を被覆し, ラメラ構造を形成していることが示唆さ れた.

洗剂残存性試験からは, 未加工布に比べて PMS 加工布 では, 洗濯洗剤の主成分であるアルキル硫酸塩 (AS) が付 着しにくく，また，す寸ぎにより容易に AS が除去される ことが明らかとなった。ささらに，三次元培養皮膚を用い た評価から, PMS 加工した生地は, 界面活性剤(SDS)の 毒性を低減させることが明らかとなった。

以上の結果から, PMS 加工した生地は化学的刺激の原 因となる界面活性剂の付着を抑制し，その毒性を低減す ることが明らかとなった，今後，皮膚障害を持つ患者の ための肌着用加工剂として, 応用が期待される.

\section{謝 辞}

本研究の遂行にあたり, 日本油脂株式会社の田中信治 博士, 福井洋樹博士, ならびに首藤健志郎博士より, ご 協力とご助言を戴きました。 心より感謝申し上げます.

\section{文 献}

1. "Guidelines for Therapy for the Treatment of Atopic Dermatitis 2005", Health Labour Sciences Research (2005).

2. M. Furue, F. Furukawa, M. Hide, and K. Takehara, The Japanese Journal of Dermatology, 114(2), 135 (2004).

3. H. Shirai, M. Kimura, T. Tsuiki, and T. Sugihara, Polyfile, 43(509), 18 (2006).

4. T. Shimizu, Y. Obayashi, Y. Tanaka, Y. Odake, M. Odera, and S. Watanabe, Japanese Journal of Dermatology, 116 (5), 767 (2006).

5. N. Yamamoto, H. Fukui, S. Yamada, and K. Shuto, JETI, 53(1), 147 (2005).

6. M. Tsuchida, and K. Shimada, Fragrance Journal, 28(12), 118 (2000).

7. N. Yamamoto, H. Irie, N. Sakamoto, K. Shuto, T. 
Yamagishi, and Y. Nakamoto, J. Oleo Sci., 55(9), 465 (2006).

8. N. Yamamoto, and K. Shuto, Preprints of the 8th SPSJ International Polymer Conference, 425, (2005).

9. H. Fukui, K. Awai, and K. Shimada, Fragrance Journal, 33(1), 97 (2005).

10. K. Awai, H. Fukui, and K. Shimada, Bio Industry, 22(9), 45 (2005).

11. K. Shimada, K. Awai, H. Fukui, and N. Yamamoto, SPC Asia, 43, 14 (2006).

12. S. Ando, H. Tsuge, and T. Mayumi, Colloid Polym. Sci.,
274(2), 178 (1996).

13. H. Matsumura, F. Mori, K. Kawahara, C. Obata, and K. Furusawa, Coll. Surf. A : Physicochem. Eng. Aspects, 92, 87 (1994).

14. “Application report No. Zeta-SCJ03010”, Sysmex (2003).

15. R. Sugihara, H. Tamai, K. Moriyama, and T. Suzawa, Yukagaku, 40(1), 32 (1991).

16. P. Greenspan, and S.D. Fowler, J. Lipid Res., 26(7), 781 (1985).

17. K. Morota, N. Morikawa, S. Morita, H. Kojima, and H. Konishi, Tiss. Cult. Res. Commun., 17, 87 (1998). 